\title{
Tavuk Embriyosu Koryoallantoik Membranında Görülen Anjiyogenez Sürecinde C-Tipi Natriüretik Peptid-3 ve Natriüretik Peptid Reseptör-B mRNA İfadelerinin Analizi: Tanımlayıcı Bir Çalışma
}

\author{
Ekin EFE ${ }^{1}$, Attila DAĞDEVİREN ${ }^{1}$, Fevziye Figen KAYMAZ ${ }^{2}$, Ahmet Çevik TUFAN ${ }^{3}$ \\ 1 Başkent Üniversitesi Tıp Fakültesi, Histoloji ve Embriyoloji Anabilim Dalı, Ankara. \\ 2 Hacettepe Üniversitesi Tıp Fakültesi, Histoloji ve Embriyoloji Anabilim Dalı, Ankara. \\ 3 Ankara Yıldırım Beyazıt Üniversitesi Tıp Fakültesi, Histoloji ve Embriyoloji Anabilim Dalı, Ankara.
}

\section{ÖZET}

Tavuk koryoallantoik membran (CAM) modeli, anjiyogenez çalısmalarında gelișimsel süreçleri takip etmek için yaygın olarak kullanılan bir modeldir. Bu çalışmada, CAM kullanılarak, embriyonik gelişimin 7. ve 20. günleri (E7 ve E20) arasında görülen anjiyogenez süreci ş̧ık ve transmisyon elektron mikroskop analizleri ile takip edilmiștir. Ayrıca, aynı günlerde alınan CAM örnekleri kullanılarak, anjiyogenez mekanizmalarında görevli [Vasküler Endotelyal Büyüme Faktörü (VEGF)-A ve Fibroblast Büyüme Faktörü (FGF)-2] ve reseptörlerinin [Vasküler Endotelyal Büyüme Faktörü Reseptörü (VEGFR)-2 ve Fibroblast Büyüme Faktörü (FGFR)-2] yanı sıra, insan C-tipi natriüretik peptid (CNP) homoloğu olan tavuk CNP-3 ve reseptörü natriüretik peptid reseptörü (NPR)-B'nin mRNA ifade düzeylerinin zamana bağımlı değişimi analiz edilmiştir. Işık mikroskobu ve elektron mikroskobu analizleri, endotel tüp benzeri vasküler yapıları yoğun olarak E7-E8 günlerinde ve koryonik mezenşim içinde bulunduğunu göstermiştir. E9-E20 günler sürecinde ise mezenşim içinde yer alan vasküler yapıların progresif gelişimi, stabilizasyonu ve kompleks dallanması gözlenmiştir. Bu vasküler gelişim sürecinde, VEGF-A ve FGF-2 mRNA ifadesi, CAM gelişimininin erken aşamalarında E7 ile E9 arasında ve E8'de pik yapacak şekilde gözlenmiştir. Bu moleküller, CAM gelişiminin geç döneminde, E16 civarında ikinci bir pik göstermiștir. CNP-3 mRNA ifadesi E16 ile E20 arasında VEGF-A ve FGF-2 mRNA ifadeleri ile es zamanlı olarak tespit edilmiş̧ir. VEGFR-2 mRNA ifadesi E7-E12 arasında gözlenirken, FGFR-2 mRNA ifadesi ilk pikini E7-E9 arasında ve ikinci pikini E16-20 arasında göstermiştir. NPR-B mRNA ifadesi ise en yüksek seviyesi E16'da olmak üzere E7-E20 arasında gözlenmiştir. Sonuç olarak elde edilen veriler, CNP-3'ün özellikle CAM gelişiminin geç döneminde (E16-E20 günleri sürecinde), NPR-B reseptörü arac1lığıyla, ileri vasküler organizasyonda rol oynayabileceğini ortaya koymuştur.

Anahtar Kelimeler: CNP. CNP-3. NPR-B. Anjiyogenez. Koryoallantoik membran (CAM).

Analysis of the mRNA Expression of C-Type Natriuretic Peptide-3 and Natriuretic Peptide Reseptor-2 in Angiogenesis of Chick Chorioallantoic Membrane: A Descriptive Study

\begin{abstract}
The chick chorioallantoic membrane (CAM) is a widely used model to follow the developmental processes in angiogenesis studies. This study aims to describe the putative involvement of CNP-3, the chick homolog of human CNP, and its receptor natriuretic peptide receptor (NPR)-B besides known angiogenic factors and their receptors, vascular endothelial growth factor (VEGF)-A/ vascular endothelial growth factor receptor (VEGFR)-2 and fibroblast growth factor (FGF)-2/fibroblast growth factor receptor (FGFR)-2, in angiogenesis of the CAM. CAM samples between developmental days E7 and E20 were collected for light microscopic and transmission electron microscopic analyses. Expression of CNP-3/NPR-B, VEGF-A/VEGR-2, FGF-2/FGFR-2 mRNA in these CAM samples were also studied between E7 and E20. Light microscopy and electron microscopy analyzes showed that, vascular organization was mostly within the chorionic mesenchyme as endothelial tube-like structures on E7-E8 days. On E9 and later, advanced blood vessels were observed within the mesenchyme. VEGF-A and FGF-2 expression were observed in the early stages of CAM development (E7-E9) with a peak at E8. These molecules showed a second peak at around E16. Co- expression of VEGF-A, FGF-2 and CNP-3 were seen at E16-E20. VEGFR-2 expression was observed between E7E12, whereas expression of FGFR-2 showed its first peak between E7-E9 and its second peak between E16-20. NPR-B expression, on the other hand, was observed between E7-E20 with its highest level at E16. In conclusion, the results revealed that CNP-3 may have a role in vascular organization via its NPR-B receptor in the later stages, i.e., E16-E20, of CAM development.
\end{abstract}

Key Words: CNP. CNP-3. NPR-B. Angiogenesis. Chorioallantoic membrane (CAM).

Geliş Tarihi: 05.Nisan.2021

Kabul Tarihi: 04.Mayıs.2021

Dr. Ahmet Cevik TUFAN

Ankara Yıldııım Beyazıt Üniversitesi,

Tıp Fakültesi, Histoloji ve Embriyoloji Anabilim Dalı.

Ankara, Türkiye.

Tel.: 05303284969

E-posta: ctufan76@gmail.com
Yazarların ORCID ID Bilgisi:

Ekin EFE: 0000-0001-6955-9839

Attila DAĞDEVIREN: 0000-0001-8990-8282

F. Figen KAYMAZ: 0000-0001-8896-2471

Ahmet Cevik TUFAN: 0000-0002-5920-0475 
Vaskülogenez ve anjiyogenez embriyoda vasküler ağın oluşumunu ve gelişimini sağlayan iki temel süreçtir $^{1-5}$. Vaskülogenez, mezoderm kökenli anjiyoblastların farklanması sonucunda endotel ve primordiyal kan hücrelerine dönüşmesi, dolayısıyla de novo olarak ortaya çıkan primitif kan damarlarının oluşumu şeklinde tanımlanır ${ }^{2-6}$. Öte yandan, anjiyogenez vaskülogenezden farklı olarak, önceden var olan kan damarlarından endotelyal proliferasyon ve migrasyon mekanizmaları ile yeni kan damarlarının oluşma sürecidir. Filizlenme ve intussusseptif olarak iki farklı anjiyogenez mekanizması tanımlanmıştır. Filizlenme şeklinde görülen anjiyogenez sürecinde endotelyal proliferasyon ve hücre göçü sonucunda endotelyal tüp oluşumu ortaya çıkar ${ }^{2,6-10}$. İntussusseptif anjiyogenez ise, önceden var olan damarların mikrovasküler büyümesinden kaynaklanır ayrıca vasküler ağın yeniden şekillenmesi ve genişlemesinden de sorumludur ${ }^{9}$.

Bazik fibroblast büyüme faktörü (bFGF, FGF-2) ve vasküler endotelyal büyüme faktörü (VEGF) hem vaskülogenezde hem de anjiyogenezde anahtar rol oynayan önemli faktörler olarak bilinmektedir ${ }^{11}$. Kan damarlarının ilk oluşum sürecinde, mezodermi uyaran bir faktör olarak bFGF, embriyoda anjiyoblastlar ve hematopoetik hücreler oluşturmak için paraksiyal ve lateral mezodermi uyarır. VEGF ise bu hücrelerin daha fazla farklılaşmasına neden olur. Anjiyoblastlar, VEGF ve reseptörü olan vasküler endotelyal büyüme faktörü reseptörü-2 (VEGFR2 / flk-1 / KDR) arac1l1ğıla endotel hücrelerine farklılaşır.

VEGF ailesi; VEGF-A, VEGF-B, VEGF-C ve VEGFD'yi içerir. Bunlar arasında VEGF-A, vaskülogenez ve anjiyogenezde önemli role sahiptir. Bu aile biyolojik işlevlerini tip III reseptör tirozin kinazlara (RTK) bağlanarak gösterir. Vasküler endotelyal büyüme faktörü reseptörü-1 (VEGR-1 / Flt-1), VEGFR-2 ve vasküler endotelyal büyüme faktörü reseptörü-3 (VEGFR-3 / Flt-4) bu kinaz ailesinin üyeleridir. Reseptörler, immünoglobulin benzeri (Ig benzeri) domain, transmembran domain ve hücre içi tirozin kalıntılarını taşıyan kinaz domaini gibi sinyal kalıntılarını içerir. $\mathrm{Bu}$ reseptörler yaygın olarak normal fizyolojik koşullar altında, endotel hücrelerinin, hematopoetik hücrelerin, makrofajların ve vasküler düz kas hücrelerinin yüzeyinde ifade edilir ${ }^{12}$.

Kan damarı oluşumu için temel olarak VEGF-A gerekli iken; lenfatik damarların oluşumu için VEGF-C gereklidir. VEGF-A, VEGFR-1 veya VEGFR-2'ye bağlanarak anjiyogenez ve vaskülogenezde aktivite gösterirken; VEGF-C, VEGFR-3'e bağlanarak lenfogenezin düzenlenmesinde görev alır ${ }^{12}$ (Şekil 1). VEGF-A, anjiyogenezde endotel hücre filizlenmesinde VEGFR-2'ye bağlanarak endotel hücrelerinin geçirgenliğinin ve göçünün artmasında rol oynar. VEGF-A'nın VEGR-1'e bağlanması, endotel hücre bölünmesini düzenleyerek gelişimsel kan damarı oluşumunu düzenler ve tüp oluşumu için endotel hücre etkileşimini destekler. VEGR-2 "knock-out” farelerde hiçbir vasküler oluşum gözlenmemektedir. Dolayısıyla, VEGF-A ve VEGR-2 etkileşimi, vaskülogenez yoluyla ilkel damarların oluşumu için gereklidir. Ayrıca, gelişimin sonraki dönemlerinde ilkel vasküler ağ yapısının anjiyogenez ile daha kompleks hale gelmesi için de VEGF-A/VEGR-2 etkileşimi gereklidir. VEGFR-1 "knock-out" farelerde, anormal derecede geniş bir vasküler oluşum gözlenmektedir. VEGR-1'in kinaz domaininin, normal vasküler gelişimde önemli olduğu bu şekilde gösterilmiştir ${ }^{13,14}$.

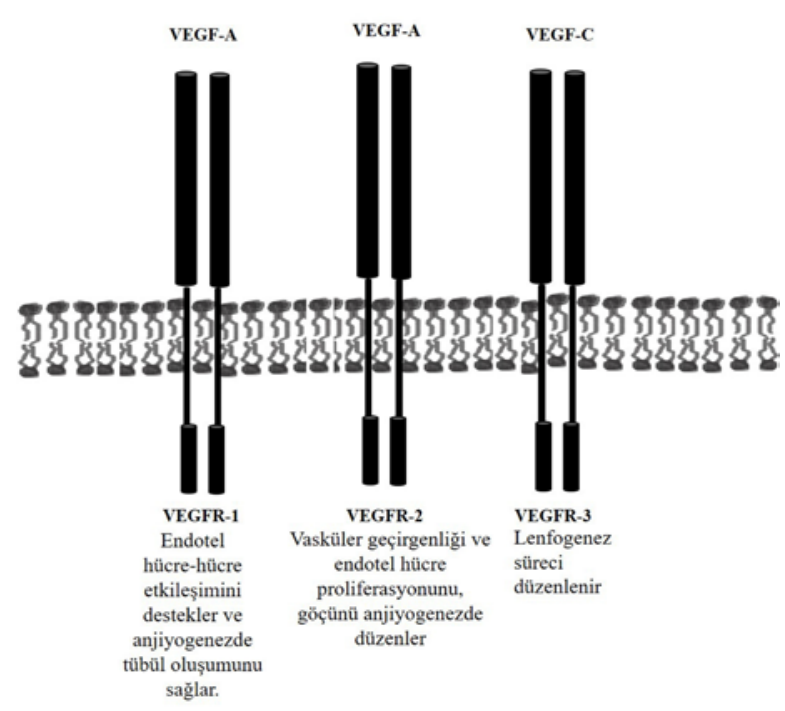

Şekil 1.

VEGF-A ile reseptörleri olan VEGFR-1 ve VEGFR-2 etkileşimi, sırasıyla yeni damarların oluşumunu ve stabilitesini düzenler. VEGF-C, lenfogenezi uyarmak için VEGR-3 aracılı̆̆lyla etkisini gösterir.

Fibroblast büyüme faktörü (FGF) ailesi ilk keşfedildiğinde, fibroblastlar üzerinde mitojenik etkiye sahip oldukları gösterilmiştir. İlerleyen yıllarda, FGF'in embriyodaki mezoderm kaynaklı vasküler endotelyal hücrelerin farklılaşmasında etkili olduğu gösterilmiştir. Ayrıca, FGF endotel hücre mitojeni olarak da bilinmektedir. Bununla bağlantılı olarak, embriyoda kan damarı oluşumu ve/veya vasküler bütünlüğün korunması için FGF-2 gereklidir. Aynı zamanda hücre büyümesi ve çeşitli hücre tiplerinin farklılaşması için güçlü bir düzenleyicidir ${ }^{15-17}$. FGF ailesinin üyeleri, farklı FGF reseptörlerinin varyantları aracılığıyla sinyal iletme özelliğine sahiptir ${ }^{17}$. Bunlardan en çok çalış1lanları, FGF-1 ve FGF-2'dir. FGF-1 ifadelenmesi esas olarak merkezi sinir sisteminde görülürken; FGF2, endotel hücreleri dahil birçok hücre tipinde ifade edilir. FGF-2, endotel hücre göçü üzerinde de etkilidir. Ayrıca, FGF-2 doku iyileşmesi, anjiyogenez, miyogenez, hematopoez gibi çeşitli süreçlerde de rol oynar ${ }^{18}$. FGF-2 etkisini, reseptör tirozin kinazlarla etkileşim yoluyla gösterir. Bu reseptör kinazlar, hücre yüzey reseptörleri olan fibroblast büyüme faktörü reseptörü- 


\section{Anjiyogenez Sürecinde CNP-3 ve NPR-B Ekspresyonu}

1 ila -4 (FGFR1-4) ve hücre yüzeyine bağlanan heparan sülfat proteoglikanlardır (HSPG'ler). FGFR'ler, FGF-2'nin hücreler üzerindeki etkilerine aracılık ederken; HSPG'ler, FGF-2'nin reseptörlerine bağlanmasını modüle eder. FGFR1 daha fazla olacak şekilde hem FGFR-1 hem de FGFR-2'nin her ikisi de endotel hücrelerinde ifade edilir ${ }^{19}$. FGF-2'nin anjiyogenezdeki etkisi, tavuk koryoallantoik membran (CAM) modeli ve/veya tavşanın korneası modeli kullanılarak gösterilmiştir ${ }^{20,21}$.

Natriüretik peptid ailesi, yapısal olarak ilişkili en az üç peptid içerir. Bunlar atriyal natriüretik peptid (ANP), beyin natriüretik peptid (BNP) ve C-tipi natriüretik peptidtir (CNP). ANP ve BNP, esas olarak sırasıyla atriyum ve ventrikül tarafindan üretilen kardiyak hormonlar olarak bilinir. Öte yandan CNP, merkezi sinir sisteminde baskındır; ancak aynı zamanda kıkırdak, epifiz plağı, kondrositler, osteoblastlar, osteoklastlar, endotel hücreleri ve vasküler düz kas hücreleri dahil olmak üzere çok çeşitli doku ve hücrelerde ifade edi$\operatorname{lir}^{22-25}$.

Natriüretik peptitler için bilinen üç tip reseptör vardır. Bunlar: natriüretik peptid reseptörü-A (NPR-A, GC-A NPR1), natriüretik peptid reseptörü-B (NPR-B, GC-B, NPR2) ve natriüretik peptid reseptörü-C (NPR-C, NPR3) olarak adlandırılırlar. Natriüretik peptitler, bu reseptörlere seçici olarak bağlanır. NPR-A için ligand seçiciliğinin sırası ANP $>$ BNP $>>C N P$, NPR-B için $\mathrm{CNP}>>\mathrm{ANP}>\mathrm{BNP}$ ve NPR-C için $\mathrm{ANP}>\mathrm{CNP}>$ BNP şeklindedir ${ }^{22,23,26}$. NPR-A ve NPR-B, insanlarda bulunan 5 transmembran guanil siklazdan ikisidir. Üçüncü natriüretik peptid reseptörü olan NPR-C, aktivitesini çoğunlukla üç peptid molekülünün lokal konsantrasyonunu ayarlayarak gösterir ${ }^{26}$. Bu özelliğinden dolayı NPR-C, natriüretik peptidlerin klirens (temizleme) reseptörü olarak bilinir ${ }^{27}$.

CNP'nin, endotel hücreleri, kardiyomiyositler ve vasküler düz kas hücreleri üzerinde, kardiyovasküler sistemde otokrin ve parakrin etkileri olduğu gösterilmiştir ${ }^{24,25,28-30}$. Son çalışmalar, CNP'nin kardiyovasküler sistemde inflamasyon, anjiyogenez, düz kas ve endotel hücre proliferasyonu, ateroskleroz, hipertansiyon ve iskemide düzenleyici bir rol oynadığını ortaya koymuştur ${ }^{25,31}$. CNP, bu süreçlerde reseptörleri olan NPR-B ve NPR-C aracılığılyla etki gösterir ${ }^{25,31}$. NPR$\mathrm{B}$, vasküler düz kas hücrelerinde ifade edilir. Bu noktada, CNP ve NPR-B etkileşimi, anjiyogenezin ilerlemesinden ziyade vasküler tonusun lokal ayarlanmasıyla ilişkilidir ${ }^{25}$. CNP'nin endotelyal hücreler üzerindeki göç etkisinin, anjiyogenezde potasyum kanallarının ATP aracılı aktivasyonu ile ilişkili olduğu da gösterilmiştir. Bu çalıșmada ${ }^{32}$, ölümsüzleștirilmiş fare beyin mikrovasküler endotel hücre hattı (BEnd.3) ve insan göbek kordonu damar endotel hücreleri (HUVECs) kullanılarak potasyum kanalları aracılığıyla CNP ve VEGF'in etkileri analiz edilmiștir. Sonuçlar, potasyum kanal aktivatörleri, CNP ve VEGF kullanımının anji- yogenezde benzer sonuçlar verdiğini göstermiştir. Ek olarak, aynı sonuçlar CAM analizi ile gösterilmiş ve potasyum kanal inhibitörleri kullanıldığında, CNP aracılı anjiyogenezin CAM yapısında bozulduğu gösterilmiştir. CNP'nin bu etkisine NPR-C'nin aracılık ettiği düşünülmüştür ${ }^{32}$. Başka bir çalışma ${ }^{31}$, CNP'nin konsantrasyona bağlı bir şekilde verildiğinde (1 $\mu \mathrm{M}$ konsantrasyonda), aort filizlenme testinde VEGF'e benzer bir yanıt ürettiğini ve bu etkinin NPR-C'ye bağlı olduğunu; ancak NPR-B'den bağımsız olduğunu göstermiştir. Ek olarak, endotelyal CNP'nin, anjiyogenez ve vasküler yeniden modellenme sürecinde iskemiye yanıt olarak NPR-C aracılı bir etki gösterdiği ve reseptörün bu etkiyi Gi uyarımı, ERK1 / ERK2 ve PI3K $\gamma$ / Akt / protein kinaz-B aracılığıyla gerçekleştirdiği gösterilmiştir ${ }^{31}$. Bu çalışmalarda, CNP/NPR-C sinyal yolunun anjiyogenezdeki rolünün altı çizilmiştir. Anjiyogenezin düzenlenmesinde CNP ile VEGF ve bFGF arasında ilişki olduğunu öne süren çalışmalar vardır. VEGF'in endotel hücrelerinde CNP salınımını inhibe ettiği ve CNP'nin VEGF üzerinde aynı etkiye sahip olduğu gösterilmiştir ${ }^{31}$. Başka bir çalışma, bFGF ve CNP arasındaki ilişkiyi göstermiştir. bFGF uyarımının aort ve beyin vasküler düz kas hücrelerinde CNP mRNA ifadesini azalttığı gösterilmiştir. Ayrıca, aort düz kas hücrelerinde bFGF'in etkisi altında TGF$\beta$ aracılı uyarmanın CNP üretimini ve salgılanmasını azalttığı gösterilmiştir ${ }^{33}$.

C-tipi natriüretik peptid, 2q24-qter bir kromozomal lokasyona sahip tek bir gen, natriüretik peptit öncüsü C'nin (Nppc) ürünüdür ${ }^{23,26}$. Houweling ve ark. ${ }^{34}$, tavuk natriüretik peptid öncü gen kümesini tanımlayarak karakterize etmiş ve bu genin organizasyonunun, memeli Nppb-Nppa kümesiyle karşılaştırıldığında yüksek oranda korunmuş olduğunu bulmuștur ${ }^{35}$. Buna ek olarak, tavuk CNP-3, insan CNP'sinin amino asit dizisiyle yüksek homoloji göstermektedir ${ }^{34}$. Dolayısıyla tavuk CAM modelinin kullandığı bu çalışmada, önceki çalışmalarımızda da ${ }^{23,35}$ kullanılmış olan CNP3/NPR-B dizilerini, revers transkripsiyon polimeraz zincir reaksiyonu (RT-PCR) ile analiz yöntemi seçilmiştir.

Tavuk embriyosu gelişiminin başlangıcında koryoallantoik membran (CAM) avaskülarize bir yapıdır. Yumurtanın inkübasyonunun 5. gününde [(embriyonik 5. gelişim günü (E5)], CAM vaskülarizasyonu başlar. Tavuk embriyosunun allantoisi, inkübasyonun 3. günü civarında ventral endoderm arka bağırsak duvarı boyunca ilerler. Embriyoyu ekstraembriyonik söloma doğru iter. E4 ve E10 arasındaki dönemde, allantoisin mezoderm tabakası (splanknik mezoderm), koryonun mezoderm tabakası (somatik mezoderm) ile birleșir ve böylece koryoallantoik membran oluşur (Şekil 2). Başka bir deyişle, CAM yapısı allantoisin epitel tabakası ile koryonun epitel tabakası arasında kalan splanknik ve somatik mezoderm tabakaların birleşmesinden oluşur. CAM yapısına katılan çift katmanlı 
mezoderm kan damarları açısından zengindir ve embriyonik dolaşıma iki allantoik arter ve bir allantoik ven aracılığıyla bağlanır. Allantoik arterler ve ven embriyonik dolaşıma katkı sağlar. Bu yapılar, memelilerde bulunan umbilikal arterler ve vene benzer ${ }^{36,37}$.

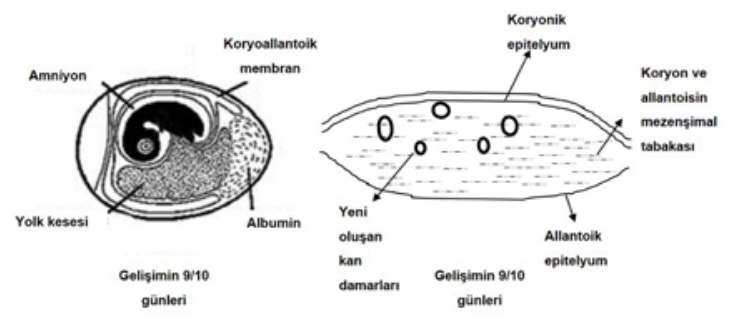

Şekil 2.

CAM, allantois ve koryon epiteli ile bunların mezenşim tabakalarından oluşur. CAM, embriyonik 4. günden itibaren gelişmeye başlar ve 10. günde gelişimini büyük ölçüde tamamlayarak yumurta kabuğunun içini tamamen kaplar. Yapısında yoğun bir vasküler ă̆ barindirir.

Tavuk CAM modeli, anjiyogenez çalışmaları için yaygın olarak kullanılmaktadır ${ }^{38-40}$. Endotel hücrelerin filizlenmesi ile izlenen anjiyogenez, E5 ila E7 gelişimi arasında görülür. $\mathrm{Bu}, \mathrm{CAM}$ vasküler büyümesinin ilk aşaması olarak düşünülmektedir. E8-E12 arasında, intususseptif anjiyogenez (intususseptif mikrovasküler büyüme) belirgindir ve E13-E14 sırasında vasküler ağ, herhangi yeni bir ağ oluşumu veya karmaşı yap1 olmaksızın hacim ve kütle olarak büyür ${ }^{40,41}$. CAM'ın genel vasküler yapısı, kabuğa en yakın koryonik epitele bitişik bulunan kılcal vasküler tabakadan ve CAM içinde serbestçe yüzen ve embriyonik hareketler ile uyumlu hareket edebilen, daha derin ve daha büyük damarlardan oluşur ${ }^{40,42}$. İlk aşamada henüz olgunlaşmamış kan damarları ve düz kas hücreleri mezoderm içinde yer alır. Kan damarları E8'e kadar çok hızlı büyür ve üzerini örten koryonik epitel hücreleri ile ilişkili kılcal pleksusa köken vererek diş çevre ile gaz alış-verişine aracılık eder ${ }^{40,43,44}$. CAM, yüzey alanında hızlı büyümeye devam eder ve E10-E11 civarında CAM, yumurta kabuğu açıldığında altında açıkça görülebilir ${ }^{40,45,46}$. E12'de CAM, iç kabuk zarının tüm yüzeyini kaplar ve E14'e kadar yüzey alanı genişlemeye devam eder ${ }^{40,47}$. E16'da CAM'in kılcal vasküler ağı ince yapısı, koryonik epitele komşu mezoderm içinde ve devamlı bir endotel tabakası ile örtülü, çevresindeki perisitlerin koryonik epitel içerisinde görüldüğü yoğun bir pleksus olarak tanımlanır ${ }^{40,48}$. CAM'in vasküler sistemi E18'de son kompleks yapısına ulaş1r ${ }^{40,49}$.

Kan damarlarının oluşumu, vaskülogenez ve anjiyogenez süreçlerini içeren kompleks bir olaydır. Büyüme faktörleri ve etki gösterdikleri sinyal yolları, bu süreçlerde önemli rol oynamaktadır. Bu çalışma, gelişimi sürecinde CAM yapısını 1 şı ve elektron mikroskop incelemelerinde tanımlamak ve CAM yapısı içerisinde görülen anjiyogenez sürecinde bilinen anjiyogenik faktörler olan VEGF-A ve FGF-2'nin yanı sıra CNP3'ün mRNA ifade profilini, dolayısıyla süreçteki olası katkısını zamansal açıdan analiz etmek için planlanmiştır.

\section{Gereç ve Yöntem}

\section{Tavuk Embriyolarının Elde Edilmesi}

$\mathrm{Bu}$ çalışma Başkent Üniversitesi Hayvan Deneyleri Yerel Etik Kurulu tarafından onaylanmış ve Başkent Üniversitesi Araştırma Fonu tarafindan desteklenmiştir (Proje no: DA20/14). “ATAK-S” soyundan fertilize tavuk yumurtaları T.C. Tarım ve Orman Bakanlığı, Tavukçuluk Araştırma Enstitüsü'nden temin edilmiştir. Yumurtalar, $37.5{ }^{\circ} \mathrm{C}$ 'de ve nemli ortamını koruyan yumurta inkübatöründe istenilen süre inkübe edilmiştir. Çalışmada \%10 oranında döllenmemiş yumurta olabileceği göz önüne alınmıştır ve buna bağlı olarak 90 adet tavuk yumurtası ile çalışılmıştır.

\section{CAM Doku Örneklerinin Toplanması, Işık Mikroskobu ve Geçirimli Elektron Mikroskobu (TEM) ile CAM Örneklerinin Yapısal Analizi}

Steril cerrahi aletlerle yumurtanın kabuğunun sivri olmayan tarafinda bir pencere açılarak E7'den E20'ye kadar CAM doku örnekleri kesip çıkarılan kabuk altından toplanmıştır. Örnekler, 1 şık mikroskopu için \%4 paraformaldehit içerisinde ve TEM için \%2 glutaraldehit solusyonunda tespit edilmiştir ${ }^{50}$. Iş1k mikroskop analizi için rutin histolojik teknikler kullanılmıştır. Gece boyu \%4 paraformaldehit tespitinden sonra, örnekler \%70 alkol içerisine alınmış ve artan dereceli alkol serisinden (\%75, \%96 ve \%100) geçirilerek dehidrate edilmiştir. Ksilol ile muamele sonrasinda parafinde 3 saat bekletilen dokular parafin bloklara gömülmüştür. Lizin kaplı lamlar üzerine 5 mikrometre kalınlığında kesitler alınmış ve ardından hematoksilen-eozin ile boyanmıştır. Işı1k mikroskopik analiz için ek olarak, \%2 gluteraldehit ile tespit edilmiş CAM örneklerinden yarı ince kesitler hazırlanmıştır. Bunun için dokular gluteraldehit tespiti sonrasında küçük parçalara bölünmüş ve ikinci defa osmiyum tetroksitle tespit edildikten sonra, fazla suyun uzaklaştırılması için artan derecelerdeki etil alkol serilerinden geçirilmiştir. Örnekler propilen oksit, gömme materyalinde (v/v) [10 ml Araldit Resin, $10 \mathrm{ml}$ Dodesenil süksinik anhidrit (DDSA), $0.5 \mathrm{ml}$ Benzildimetilamin (BDMA), $1 \mathrm{ml}$ Dibütil fitalat] 30 dakika bekletilmiştir. Sonrasında, \%25 propilen oksit + \%75 kısım gömme materyalinde (v/v), karıştırıcı üzerinde, oda ısısında, 2 saat karıştırılmıştır. Son olarak dokular gömme materyali ile gömme kapsülüne gömülmüştür. Hazırlanan bloklardan ultramikrotom ile 1 mikrometre kalınlığında kesitler alınarak \%1 toluidin mavisi ile boyanıp 1şık 
mikroskobu ile incelenmiştir. Müsküler arterlerinin gelişimi, arteriyollerin ilk görüldüğü zaman noktası, CAM yapısındaki bağ dokusu kalınlığı ve damar duvar kalınlığındaki değişim gibi tanımlayıcı parametreler 1 şı mikroskop ile incelenmiştir. HematoksilenEozin ile boyanan preparatlar ve toluidin mavisi ile boyanan yarı ince kesitler Leica DFC 500 dijital kamera bağlı olan 1şık mikroskop ile (Leica DM 3000, Almanya) fotoğraflanmıştır.

TEM analizi sürecinde yarı ince kesitler için hazırlanan bloklardan elde edilen $90 \mathrm{~nm}$ kalınlığındaki ince kesitler kullanılmıştır. Yarı ince kesitler ile işaretlenen bölgelerden alınan ince kesitler 100 ya da 200 mesh'lik bakır gridler üzerine alınmıştır. Alınan kesitler kontrast sağlamak amaciyla, uranil asetat ve kurşun sitrat ile boyanmıştır. Elektron mikroskobu, vasküler dallanma noktalarını görselleştirmek, endotel hücrelerdeki, granül depolayan hücrelerdeki ve koryonik ve allantoik epiteldeki değişiklikleri gözlemlemek için kullanılmıştır. İnce kesitler Gatan Orius SC-1000 dijital kamera bağlı olan geçirimli elektron mikroskop (Jeol JEM 1400, Japonya) ile incelenmiştir.

\section{RNA İzolasyonu ve Revers-Transkriptaz Polimeraz Zincir Reaksiyon (RT-PCR) Analizi}

Belirlenen gelişim günlerinde CAM örneklerinden RNA izolasyonu, daha önce tarif edildiği şekilde ${ }^{23}$, Trizol solüsyonu (Tri-reagent, Sigma, Almanya) kullanılarak yapılmıştır. Bunun için, E7 ile E20 arasında kalan süreçte CAM örnekleri günlük olarak toplanmıştır (E11, E14, E18 hariç). Toplam RNA konsantrasyonu ve saflığ1 A260/A280 oranı kullanılarak hesaplanmıştır (>1.8). İki aşamalı RT-PCR reaksiyonu için üretici firmanın (OneScript ${ }^{\circledR}$ Plus cDNA Synthesis Kit abm, Kanada) önerileri doğrultusunda önce $1 \mu \mathrm{g}$ total RNA revers-transkriptaz (RT) reaksiyonu için kullanılmıştır ve ardından PCR reaksiyonu ile analizi istenen mRNA'lar amplifiye edilmiştir. RT reaksiyonları termal döngü cihazı kullanılarak iki aşamalı şekilde gerçekleştirilmiştir (Birinci aşama: 1 döngü $65{ }^{\circ} \mathrm{C}$, 5 dakika ve $+4{ }^{\circ} \mathrm{C}, 1$ dakika. İkinci aşama: cDNA elde etmek için (ters transkripsiyon), 1 döngü $50{ }^{\circ} \mathrm{C}, 50$ dakika, $85{ }^{\circ} \mathrm{C}, 5$ dakika ve $+4{ }^{\circ} \mathrm{C}, 5$ dakika). Elde edilen cDNA ürünleri PCR için kullanıma kadar -20 ${ }^{\circ} \mathrm{C}$ 'de saklanmıştır.

Analizi istenen genler için PCR döngü koşulları optimize edilmiştir ve normalizasyon aşamasında kontrol olarak kullanılan gliseraldehit fosfat dehidrogenez (GAPDH) için PCR protokolünde 27 döngü ve analiz edilen diğer tüm genler için 30 döngü optimum olarak belirlenmiştir. Analiz edilen genler ve kullanılan primerler Tablo I'de listelenmiştir. Termal döngü cihazı kullanılarak gerçekleştirilen PCR koşulları şunlardır: 1 döngü, $95{ }^{\circ} \mathrm{C}$, 12 dakika (aktivasyon); 25-30 döngü, $95{ }^{\circ} \mathrm{C}, 1$ dakika (denatürasyon), $55-58{ }^{\circ} \mathrm{C}, 1$ dakika (primerlerin yapışması), $72{ }^{\circ} \mathrm{C}, 1$ dakika (uzama); 1 döngü, $72{ }^{\circ} \mathrm{C}$, 10 dakika (son uzama). Elde edilen
PCR ürünleri $+4{ }^{\circ} \mathrm{C}^{\prime} \mathrm{de}$ saklanmıștır. PCR ürünleri agaroz jel elektroforezi ve etidyum bromür boyama ile görselleştirilmiştir. Elde edilen PCR ürünlerinin dansitometrik analizleri Image $\mathrm{J}$ programı kullanılarak gerçekleştirilmiştir (https://imagej.nih.gov/ij/ download.html). Her gelişimsel güne ait spesifik gen ifadeleri, aynı güne ait GAPDH ölçüm sonucu kullanılarak normalize edilmiştir ve sonuçlar grafikler şeklinde sunulmuştur.

Tablo I. Revers-Transkriptaz Polimeraz Zincir Reaksiyonu için kullanılan primerler.

\begin{tabular}{|c|c|c|c|}
\hline $\begin{array}{l}\text { Hedef } \\
\text { Gen }\end{array}$ & $\begin{array}{l}\text { Kullanılan Primer } \\
\text { Sekansları }\end{array}$ & Ürün & $\begin{array}{c}\text { Gen Bankası } \\
\text { Ulaşım Numarası }\end{array}$ \\
\hline VEGF-A & $\begin{array}{l}\text { F: } \\
\text { CGGAAGCCCAACGAAGTTAT } \\
\text { C } \\
\text { R: } \\
\text { CCTTCCCCTTTCCTCGCTTT }\end{array}$ & 349 bç & $\begin{array}{l}\text { NM205042.2 (bu } \\
\text { makale) }\end{array}$ \\
\hline $\begin{array}{l}\text { VEGFR- } \\
2\end{array}$ & $\begin{array}{l}\text { F: } \\
\text { AGTCATAGGCAACGACACCG } \\
\text { R: } \\
\text { TGCACGCTTTTCCTTGATGG }\end{array}$ & 529 bç & $\begin{array}{l}\text { NM001004368.1 (bu } \\
\text { makale) }\end{array}$ \\
\hline FGF-2 & $\begin{array}{l}\text { F: } \\
\text { AAGCGGCTCTACTGCAAGAA } \\
\text { C } \\
\text { R: } \\
\text { TTGGTCCGGGCTTGTACTGT }\end{array}$ & 325 bç & $\begin{array}{l}\text { NM205433.1 (bu } \\
\text { makale) }\end{array}$ \\
\hline FGFR-2 & $\begin{array}{l}\text { F: } \\
\text { CAGCTGACTCAAGCTCCTCC } \\
\text { R: } \\
\text { CATACAGCGGACCATCCTGG }\end{array}$ & 393 bç & $\begin{array}{l}\text { NM205319.2 (bu } \\
\text { makale) }\end{array}$ \\
\hline CNP-3 & $\begin{array}{l}\text { F: } \\
\text { AAGAGAGGGATCGTGAGCAA } \\
\text { R: } \\
\text { TCCTGGACAGACCCTTTTTG }\end{array}$ & 201 bç & XM427055 (23) \\
\hline NPR-B & $\begin{array}{l}\text { F: GCCTGCTCCGAGTACGTG } \\
\text { R: GTGCAGGTGGGAGACGAA }\end{array}$ & 252 bç & XM427055 (23) \\
\hline GAPDH & $\begin{array}{l}\text { F: AGTCATCCCTGAGCTGAAG } \\
\text { R: } \\
\text { AGGATCAAGTCCACAACACG }\end{array}$ & $330 \mathrm{bç}$ & J00849 (23) \\
\hline
\end{tabular}

*dipnot: F: "Forward” primer, R: "Reverse” primer, bç: baz çifti

\section{Bulgular}

\section{CAM Yapısının Işılk Mikroskopik Analizi}

CAM gelişimi sürecindeki yapısal değişimleri incelemek için, Hematoksilen-Eozin ile boyanmış kesitler ve toluidin mavisi ile boyanmış yarı ince kesitler 1 şık mikroskop kullanılarak analiz edilmiştir. E7'de CAM mezenşimi içinde endotel tüp yapıları gözlenmiştir (Şekil 3A ve B). E12'de ana kan damarlarının çapının arttığı ve mezenşimden farklılaştığı öngörülen düz kas hücreleri ile bu damarların etrafının sarıldığ 1 ve stabi- 
lize edildiği gözlenmiştir (Şekil 3C). Sırasıyla E12 ve E13'te CAM yapısı içinde tanımlanmış müsküler arterler (Şekil 3C) ve orta büyüklükte ven yapıları görülmüştür (Şekil 3D).

E15'te, tunika muskularis tabakasındaki düz kas say1sındaki artışla tanımlanan müsküler arterler görüntülenmiştir (Şekil 4A). CAM mezenşim hücre yoğunluğunun ve buna paralel olarak CAM kalınlığının E15 ile E17 arasında arttığı görülmüştür (Şekil 4B ve C). Müsküler arterlerinin yapısı, tunika adventisyanın organizasyonu ile E15-E19 arasında daha fazla gelişme göstermiştir (Şekil 4B-D ve Şekil 5A-B). E20'de kalın bir mezenşim ve incelmiş koryonik ve allantoik epitel yapıları gözlenmiştir (Şekil 4E). Ek olarak, gelişimin ileri evrelerinde, CAM mezenşiminde kan damarlarının koryona oldukça yaklaştığı gözlenmiştir (Şekil 4F).

\section{CAM Vasküler Yapısının TEM Analizi}

E7'de CAM koryonik epiteli altında ve mezenşim içinde endotel tüp yapıları gözlenmiştir (Şekil 6A). Koryonik epitel bu aşamada iki tabakalı olarak gözlenmiş olup, bu hücre tabakaları arasında desmozomlar görülmüştür (Şekil 6A). Ek olarak, hem mezenşim hücrelerinde hem de endotel hücrelerinde perinükleer alanda bulunan belirgin bir granüllü endoplazmik retikulumu (GER) gözlenmiştir (Şekil 6B-D).

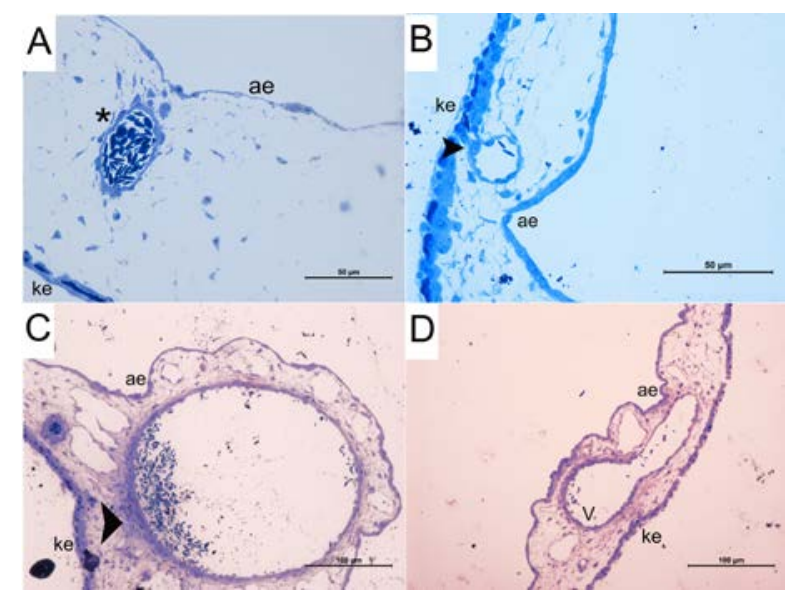

Şekil 3.

Toluidin mavisi boyama metoduyla E7, E12, E13'de boyanan CAM örneklerinin ışı mikroksop ile incelenmesi. E7'de yeni oluşan endotel tüp yapılarının mezenşim içerisinde gösterilmesi (yıldız işareti*) (A, X400). E12'de koryonik epitel altında ve mezenşim tabakasında görülen vasküler yapılar (B, X400).

E12'de mezenşimde görülen müsküler arter yapısı (ok başı) (C, X200). E13'de mezenşim tabakasında görülen ven yapisı (D, X200). ae: allantoik epitel, ke: koryonik epitel, Er: eritrositler, V: ven.

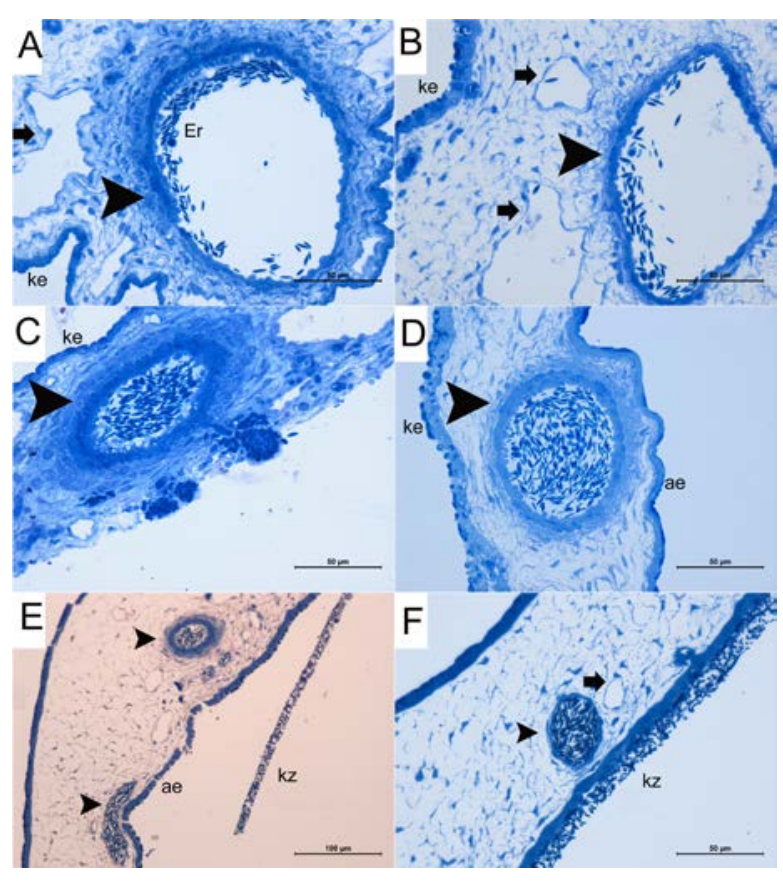

Şekil 4.

Toluidin mavisi boyama metoduyla E15, E16, E17 ve E19'da boyanan CAM örneklerinin mikroskop ile incelenmesi. E15'te lümeninde eritrositler ve lümen etrafinda belirgin tunika media bulunan müsküler arter yapısı (kalın ok başı) komşuluğunda ven yapısı (ok) (A, X400). E16'da mezenşim tabakasında venöz yapılar (oklar) ve gelişmiş müsküler arter (B, X400). E17 ve E19'da mezenşim tabakasında duvar yapısı gelişkin müsküler arter yapıları (kalın ok başı) (C, D, X400) E20'de koryonik epitel altındaki mezenşim tabakasında yoğunlaşan lümeni ve duvarı belirgin damar yapısı (ok başı) ve yanında ince kılcal damar yapısı (ok) görüldü (E, X200 ve F, X400). ae: allantoik epitel, ke: koryonik epitel, Er: eritrositler, kz: kabuk zarl

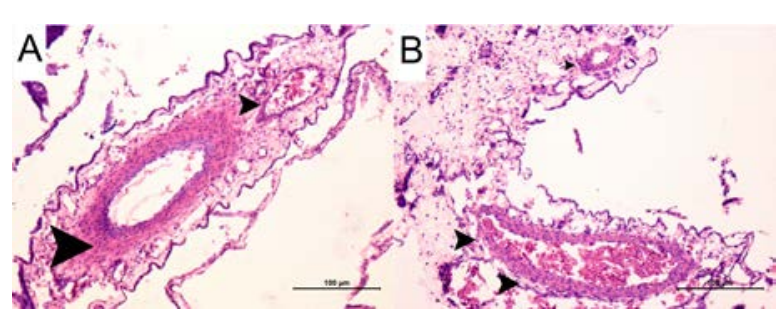

Şekil 5.

Hematoksilen-Eozin boyama metodu kullanılarak E16'da boyanan örneklerin ışık mikroskop ile incelenmesi. E16'da CAM mezenşim içerisinde yer alan çeşitli boyutlarda vasküler yapıların gösterilmesi (ok başlarl) (A, B X200). 


\section{Anjiyogenez Sürecinde CNP-3 ve NPR-B Ekspresyonu}

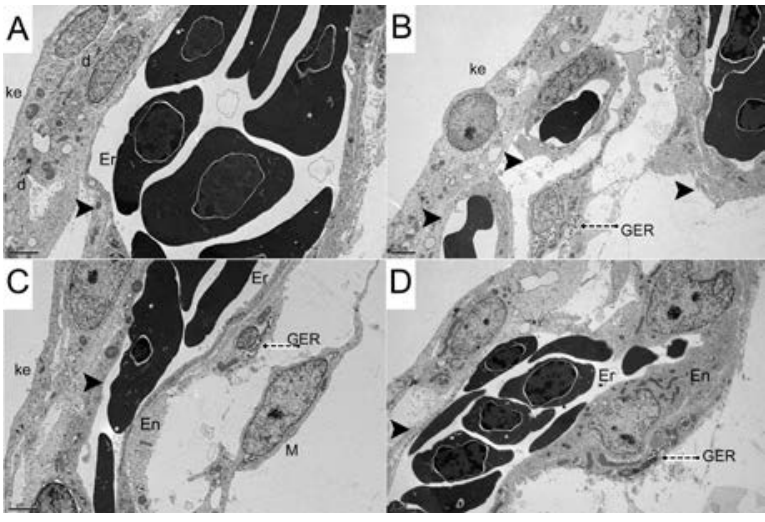

Şekil 6.

E7'de CAM örneklerinin ince yapısının TEM ile incelenmesi. CAM yapısindaki damarlar. Koryonik epitelin iki katl görünümü ve desmozomlar (A, X8000). Koryonik epitele komşu lokalizasyonda kllcal damar yapıları (ok başı) (B, X6000). Koryona komşu yerleşimli damar endotelinin yakınına yerleşmiş mezenşim hücresi ve belirgin GER yaplsı (C, X8000). Perinükleer bölgeye lokalize GER yapisl (kesikli ok) belirgin endotel ile çevrili kan damarı (D, X6000). ke: koryonik epitel, M: mezenşim hücresi, Er: eritrositler, En: endotel hücresi, d: desmozom, GER: granüllü endoplazmik retikulumu.

E8'de, CAM mezenşim tabakasında artmış kolajen sentezi görülmüştür (Şekil 7A). Allantoik epitel hücreleri ve bazal lamina arasındaki desmozomlar, E8'de açıkça gözlenmiştir. Allantoik epitelde beklenildiği gibi damar oluşumuyla ilgili herhangi bir yapı gözlenmezken, lipid damlacıklarının varlığı dikkati çekmiştir (Şekil 7B). Kan damarları, E8'de mezenşim içerisinde kolayca ayırt edilebilmiştir (Şekil 7C). Mezenşimde görülen bu kan damarları belirgin endotel hücrelerine sahiptir (Şekil 7D). Ek olarak, koryonik epitel ile yakın temas halinde endotel tüp yapıları gözlenmiştir (Şekil 7E) ve bu oluşumlarda intussuseptif anjiyogenezi düşündüren sütun benzeri oluşumlar görülmüştür (Şekil 7F).

Koryonik epitel, E12'de çok katmanlı bir yapıda görülmüştür. Koryonik epitel komşuluğunda gelişen CAM vasküler yapıları devamlı şekilde endotel tüpleri olarak gözlenmiştir (Şekil 8A). Ayrıca, bu kılcal damarlar, E7'ye kıyasla koryonik epitelin yüzeyine çok daha yakın yerleşim göstermektedir (Şekil 8B). Ayrıca endotel hücrelerde heterokromatin E15'te kan damarlarının etrafındaki perivasküler hücrelerin artışı görülmüştür. E15'te vasküler organizasyonun küçük çaplı vasküler yapılara kadar ilerlediği, bu yapıların duvarlarında perisitlerin, lümenlerinde ise eritrositlerin yer aldığı gözlenmiştir (Şekil 9A). Vasküler yapılara komşu eozinofilik hücrenin varlığı görülmüsştür (Şekil 9A). Özetle, bu aşamada koryonik epitele komşu vasküler organizasyonda artış dikkati çekmiştir (Şekil 9B).

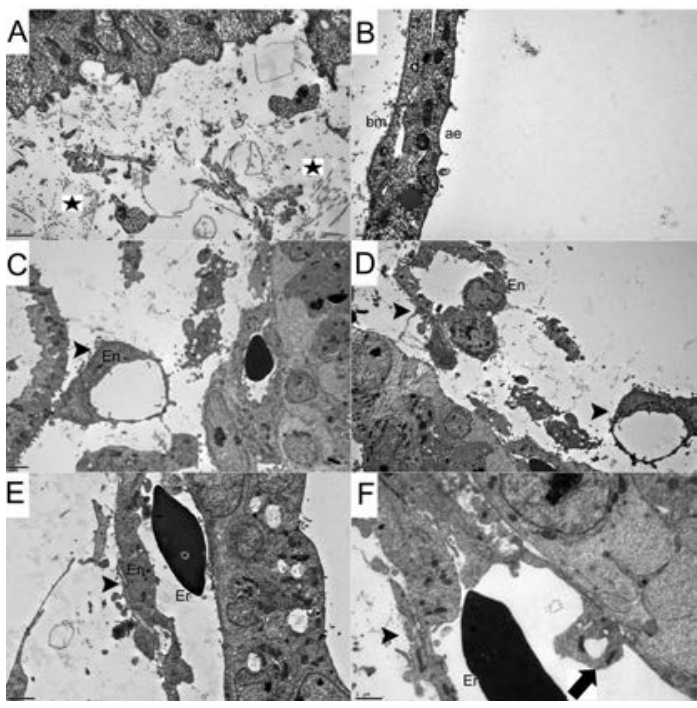

Şekil 7.

E8'de CAM örneklerinin ince yapısinin TEM ile incelenmesi. Mezenşim tabakasinda kollajen lifleri (ylldız işareti *) (A, X15000). Desmozomlar, lipid damlaciklart ve belirgin bazal membran (B, X20000). Mezenşim içerisinde vasküler yapılar (C, X6000, D, X5000, E, X8000). Endotel hücrelerinde oluşan sütun benzeri yapı (kalın ok) (F, X15000). ae: allantoik epitel, bm: bazal membran, d: desmozom, Er: eritrositler, En: endotel hücresi.

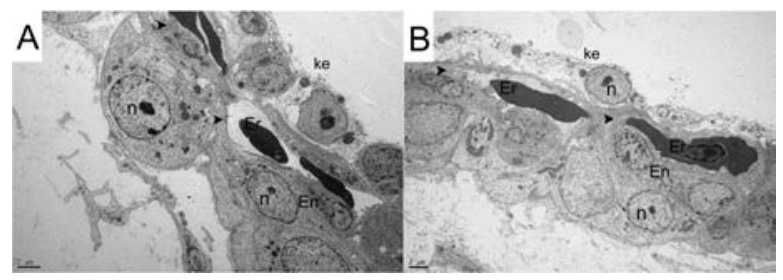

Şekil 8.

E12'de CAM örneklerinin ince yapısinin TEM ile incelenmesi. Koryonik epitel hücreleri arasinda sayıca artan ve yüzeye yakin konumlanan kalcal vasküler yapılar (ok başı ile gösterilen) (A, X6000 ve B, X5000). Ayrıca E12'de nükleolus (n) yapıları belirgin görülen koryonik epitel hücreleri gözlenmiştir. ke: koryonik epitel, Er: eritrositler, En: endotel hücresi, n:nükleolus.

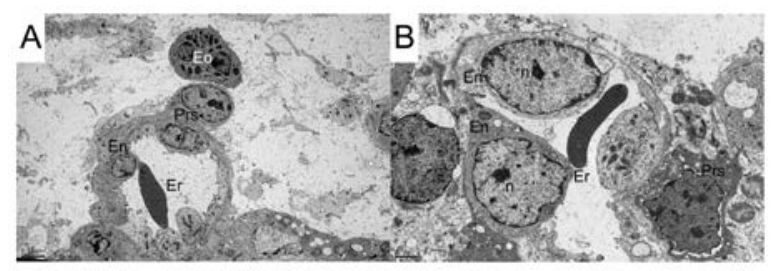

Sekil 9.

E15'de CAM örneklerinin ince yapısinin TEM ile incelenmesi. Eozinofil benzeri hücre komşuluğunda, perisitler ile çevrilmiş bulunan vasküler yapı (A, X6000). Nükleolus (n) yapılar belirgin endotel ile çevrilmiş bir lümeni ve perisitleri bulunan vasküler yар (B, X12000). Er: eritrositler, n: nükleolus, En: endotel hücresi, Prs: perisit, Eo: eozinofil benzeri hücre. 
E20'de E15'e göre daha gelişmiş ve mezenşime yerleşmiş kan damarları görülmüştür (Şekil 10A). Ayrıca, koryonik epitel altında ve yakın komşuluğunda yay1lım gösteren endotel tüp yapısındaki kan damarları da gözlenmiştir (Şekil 10B). CAM mezenşiminde farklı büyüklükte kan damarları görülmüştür (Şekil 10C-D). $\mathrm{Bu}$ durum vasküler organizasyonun kompleks bir yapıya eriştiğini düşündürmüştür. E20 için en çarpıc bulgu, hem allantoik hem de koryonik epitellerin çok katmanlı yapısının ve bu epitel hücreleri arasında desmozomların gözlenmiş olmasıdır. Koryonik epitel yüzeyindeki parmak benzeri uzantılarla çok katlı bir görünüm sergilerken (Şekil 10E); allantoik epitel daha fazla katlı bir görünüme sahip olarak görüntülenmiştir (Şekil 10F).

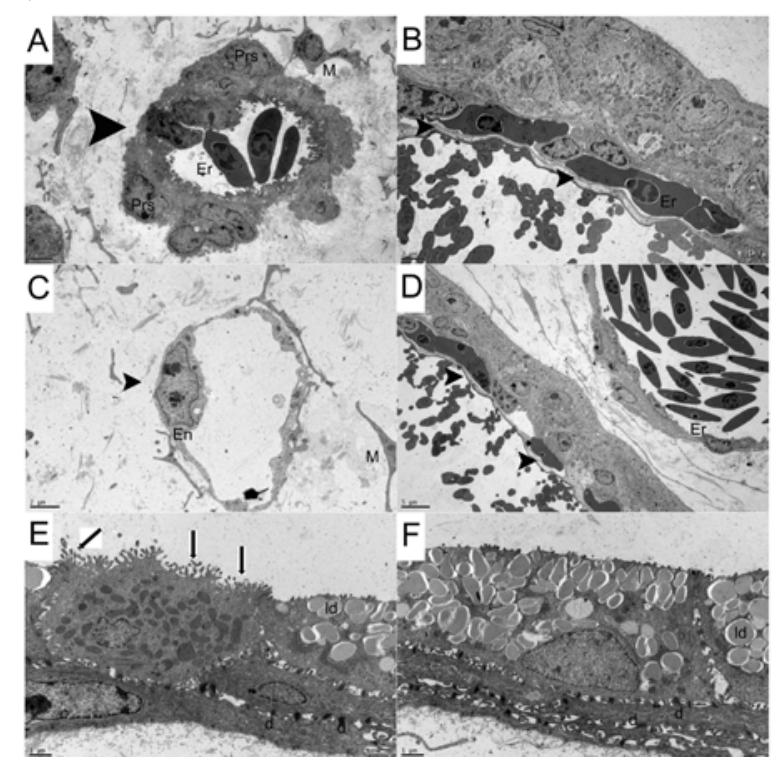

Sekil 10.

E20'de CAM örneklerinin ince yapısının TEM ile incelenmesi. Mezenşim içinde etrafinda perisit ve mezenşim hücresi görülen arter benzeri gelişmiş vasküler yapı (A, X6000) ve koryonik epitel komşuluğunda sayıca artış gösteren kapiller vasküler yapılar (ok başı) (B, X6000). Mezenşim içerisinde bir vasküler yapı (C, X8000) ve mezenşimde daha kalın bir duvara ve geniş lümene sahip kan damarl (D, X3000). Koryonik epitelin yüzeyinde parmaksı çıkıntılar (oklar) dik-

kati çekmiştir (E, X12000). Desmozomlar en çok,

katmanlı allantoik epitelde görülmüş ve allantoik epitelde artmış lipid damlacıkları (ld) sayısı gözlenmiştir (F, X12000). Er: eritrositler, En: endotel hücresi, Prs: perisitler, M: mezenşim hücresi, d: desmozom, ld: lipid damlacıklar

CAM Örneklerinde VEGFA, FGF-2, CNP-3 ve Bu Ligandlarin Reseptörlerinin Zamana Bağl mRNA Ifadelerinin Analizi

CAM gelişimi sürecinde görülen vasküler yapılanmaya paralel olarak, VEGF-A (Şekil 11A), FGF-2 (Şekil 11B) ve CNP-3 (Şekil 11C) ve bu ligandların reseptörleri olan VEGFR-2 (Şekil 11A), FGFR-2 (Şekil 11B) ve NPR-B'nin (Şekil 11C) zamana bağlı mRNA ifade düzeyleri RT-PCR ve etidyum bromür boyalı agaroz jel elektroforezi ile analiz edilmiştir. Elde edilen dansitometrik analiz sonuçları aynı zaman noktalarına karşılık gelen GAPDH ölçüm değerleri kullanılarak normalize edilmiştir.
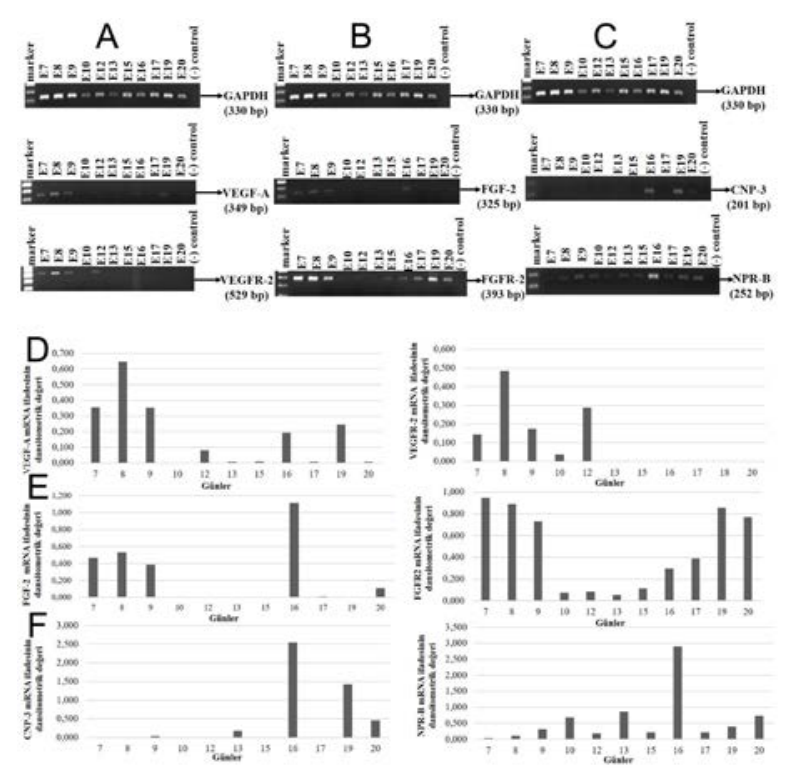

Şekil 11.

E7-E20 sürecinde (E11, E14, E18 hariç) VEGFA/VEGFR-2 (A), FGF-2/FGFR-2 (B) ve CNP-3/NPR$B(C) R T-P C R$ analizlerinin agaroz jel görüntüleri. E7-E20 sürecinde (E11, E14, E18 hariç) VEGFA/VEGFR-2 (D), FGF-2/FGFR-2 (E) ve CNP-3/NPR$B(F) m R N A$ ifadelerinin dansitometrik analiz sonuçları (sonuçlar aynı zaman noktasındaki GAPDH mRNA ifade düzeyine göre normalize edilmiştir).

VEGF-A ve FGF-2 mRNA ifadesi, reseptörleri ile uyumlu olacak şekilde E7-E9'da gözlenmiş olup, E8'de pik yaptıkları görülmüştür (Şekil 11D-E). VEGF-A ve FGF-2'nin mRNA ifade düzeylerinin E10-E15 arasında azaldığı tespit edilmiştir (Şekil 11D-E). VEGF-A mRNA ifadesinde E16-E19 arasında ikinci bir artış gözlenmiş olmasına rağmen, VEGFR-2 mRNA ifadesi E12'den sonra azalmış ve kaybolmuştur (Şekil 11D). FGF-2 mRNA ifadesi E16'da ikinci bir artış gösterirken, FGFR-2 mRNA ifadesi E15-E20 arasında kademeli olarak artmış ve ikinci kez en yüksek seviyesine E19'da ulaşmıştır (Şekil 11E).

CNP-3 mRNA ifadesi ilk olarak E13'te gözlenmiş olup, en yüksek seviyesine E16'da ulaştığg tespit edilmiştir (Şekil 11F). NPR-B mRNA ifadesinin ise tüm CAM gelişimi boyunca gözlenmesine rağmen en yüksek seviyesine, ligandı olan CNP-3 mRNA ifadesine paralel olarak, E16'da ulaştığ gözlenmiştir (Şekil 11F). 


\section{Tartışma ve Sonuç}

Bu çalışmada, tavuk embriyosu modeli kullanılarak, E7-E20 arasında CAM üzerinde görülen anjiyogenez süreci 1ş1k ve transmisyon elektron mikroskop analizleri ile takip edilmiștir. Ayrıca, aynı günlerde alınan CAM örnekleri kullanılarak, anjiyogenez mekanizmalarında rol aldığı bilinen faktörlerin (VEGF-A ve FGF-2) ve reseptörlerinin (VEGFR-2 ve FGFR-2) yanı sıra, insan CNP homoloğu olan tavuk CNP-3 ve reseptörü NPR-B'nin mRNA ifade düzeylerinin zamana bağımlı değişimi analiz edilmiştir. Çalışmanın amac1, CNP-3'ün ve reseptörü olan NPR-B'nin CAM yapısı içerisinde görülen anjiyogenez sürecindeki mRNA ifade profilini, dolayısıyla süreçteki olası katkısını zamansal açıdan analiz etmek ve tanımlamak olarak planlanmıştır.

Literatürde CAM gelişimi, koryonik ve allantoik epitel ve bunların mezenşim tabakalarının morfolojisi ve moleküler özellikleri dikkate alınarak evrelendirilmiş$\operatorname{tir}^{41,50}$. Bu evreleme genellikle gelişimin erken, ileri ve geç aşamaları şeklinde ifade etmektedir. Bu doğrultuda çalışmamızda, CAM yapısında anjiyogenezi aşamalandırmak için 1şık mikroskop analizleri kullanılmıştır. Sonuç olarak, damarların gelişim düzeyi ve damar duvarının yapısı ve kalınlığı dikkate alınarak çalışmamızda E7-E12 erken, E13-E18 ileri ve E18E20 anjiyogenezin geç evreleri olarak belirlenmiştir.

VEGF-A, anjiyogenez sürecinde reseptörlerinden biri olan VEGFR-2 aracılığıyla endotel hücre proliferasyonunu, göçünü ve endotel hücre sağkalımınını sağlayarak önemli bir rol oynamaktır ${ }^{4,5}$. Bu nedenle CAM vasküler gelişimi üzerine yapılan çalışmalar VEGF-A üzerinde yoğunlaşmıştır ${ }^{41}$. Bu çalışmada gösterilen ve E7-E9 arasında, diğer bir deyişle CAM vasküler gelişiminin erken döneminde artan VEGF-A mRNA ifadesi literatürle uyum göstermektedir ${ }^{41,51}$. Bu veriler, E7-E12 arasındaki süreçte, mezenşimde endotel tüplerin varlığını gösteren 1 şık mikroskop analizlerimizle de desteklenmiştir (Şekil 3A-B). Anjiyoblastik hücrelerin, VEGF-A sinyali ile prolifere olan ve vaskülogenez/anjiyogenez süreçlerine katılan endotelyal hücrelere farklılaştığı düşünülmüştür. E7-E12 arasında VEGF-A'ya eşlik eden VEGFR-2 mRNA ifade profili de sonuçları desteklemektedir (Şekil 11D). Bu erken dönem, yeni kan damarlarının oluşumu ve gelişmesi, yani vaskülogenez oluşması ve anjiyogenezin başlaması için uygun zaman olarak kabul edilmiştir. Ayrıca, E7'de görülen ve özellikle kan damarlarının endotel hücrelerinde bulunan perinükleer bölgede belirgin olan granüllü endoplazmik retikulumu (GER) yapısı, VEGF-A ve FGF-2 sentezini kapsadığı düşünülen protein sentezi ile ilişkilendirilmiştir. $\mathrm{Bu}$ bulgular, damar oluşumu ve gelişiminde endotel hücre filizlenmesi aracılığıyla gerçekleşen anjiyogenezde VEGF-A ve VEGR-2 arasındaki ilişkinin uyumluluğunu CAM anjiyogenezi için de desteklemektedir. Özellikle, E12'de gözlenen koryonik epitelden tomurcuklanan endotel tüp yapılarının varlığı henüz oluşmaya başlayan kan damarlarını ve bu damarlardan anjiyogenez ile gelişen damarların organizasyonunu işaret etmektedir (Şekil 3B). Ayrıca, E8'de gözlemlenen sütun benzeri yapılar, bu dönemde literatürde gösterilen ${ }^{41}$ ve VEGF-A ile ilişkili olduğu belirtilen intussuseptif anjiyogenez ile de ilişkilendirilebilir. Ancak burada instussuseptif anjiyogenez konusunda daha net bilgiler elde edebilmek için ileri çalışmalara ve seri kesitlerin analizine ihtiyaç duyulmaktadır.

FGF-2, hem erken hem de geç anjiyogenezde rol oynamaktadır ve etkisini VEGF-A gibi diğer anjiyogenik faktörlerin ifadesini kontrol ederek göstermektedir ${ }^{52,53}$. FGF-2'nin bu anjiyogenik etkisi, in vitro çalışmalarda CAM modeli kullanılarak da incelenmiştir ${ }^{44,51,54}$. Çalışmamızda, FGF-2 mRNA ifadesi ilk olarak E7-E9 arasında ve ikinci olarak E16-E20 arasında olmak üzere iki pik düzey göstermiştir (Şekil 11E). FGF-2, endotel hücrelerinin prolifere olduğu, göç ettiği ve anjiyogenez aracılığıyla yeni tübül yapılarını oluşturduğu düşünülen bu günlerde VEGF-A ile birlikte ifade edilmektedir. FGF-2 ve VEGF-A mRNA ifadelerinin, CAM gelişiminin erken aşamalarında birbirleriyle örtüşmekte olduğu gösterilmiştir (Şekil 11D-E). E7E9 arasında CAM yapısında yeni damarların oluşumunun gözlenmesi, FGF-2'nin bir endotel hücre mitojeni olarak VEGF-A ile sinerjistik etkiler gösterebileceği hipotezini desteklemektedir. Ayrıca FGF-2'nin yalnızca endotelyal hücreler üzerinde mitojenik etkileri yoktur. Fibroblastların çoğalmasını da düzenlediği bilinmektedir. FGF'in fibroblastlar üzerindeki bu etkisinin, E15 ile E17 arasında müsküler arter yapıs1 gösteren ileri arterlerin duvar yapılarında yer alan düz kas ve bağ doku tabakalarının organizasyonunu açıklayabileceği düşünülmüştür. FGF-2 ve FGFR-2'nin her ikisi de endotel hücrelerinde ve vasküler düz kas hücrelerinde ifade edilmektedir. FGF-2, bu reseptörü aracılığıyla endotel hücreleri üzerindeki etkisini göstermektedir $^{17,55}$. FGFR-2 mRNA ifadesi, E7-E9 arasında ve E16'da kendi ligandı ile eşzamanlı olacak şekilde gösterilmiștir (Şekil 11E). Bu gözlem, FGF2'nin FGFR-2 ile damar gelişiminin ileri evresinde etki gösterdiği hipotezini güçlendirmektedir.

E20'de CAM mezenşim içerisinde hem büyük lümenli ve gelişkin duvar yapısına sahip müsküler arterlerin, hem de küçük lümenli ve ince duvar yapısına sahip vasküler yapıların varlığı gözlenmiştir. Ayrıca, koryon epiteline komşu arterioller ve kapiller vasküler yapılar da gözlenmiştir. Vasküler yapıların bu şekilde farklı büyüklük ve konumlarda düzenlenmesi ve kompleks bir yapıya değişimi, muhtemelen yumurtadan çıkmadan önce civcivin artan oksijen ihtiyacıyla ilişkilendirilmektedir.

CNP'nin kardiyovasküler sistemde rolü olduğu bilinmektedir $^{30}$. CNP'nin, insan aortik endotel hücrelerin- 
den elde edilen hücre kültüründe ifade edildiği gösterilmiştir ${ }^{24}$. Ayrıca CNP reseptörlerinden biri olan NPR-B'nin sadece merkezi sinir sisteminde bulunmadığı; aynı zamanda kan damarlarında da ifade edildiği bulunmuştur $^{28}$. Bu nedenle, CNP'nin reseptörü NPR-B aracılığıyla kardiyovasküler bir role sahip olduğu düşünülmektedir ${ }^{56}$. Ek olarak, CNP'nin NPR-C yoluyla vasküler fonksiyonu düzenleme, vasküler yeniden modelleme ve anjiyogenezi düzenleme üzerinde etkileri olduğu gösterilmiştir ${ }^{31}$. Çalışmamızda, CNP-3'ün ve reseptörü olan NPR-B'nin CAM yapısı içerisinde görülen anjiyogenez sürecindeki mRNA ifade profilini, dolayısıyla süreçteki olası katkısını zamansal açıdan analiz etmek ve tanımlamak amaçlanmıştır.

CAM yapısı içerisinde görülen anjiyogenez sürecinde CNP-3 mRNA ifadesi ilk olarak E13'de görülmüş olup, E16'da pik seviyesine ulaşmıştır (Şekil 11F). E16'da FGF-2 ve CNP-3'ün eș zamanlı ifade edildiği gözlenmiştir (Şekil 11E-F). Bu sonuçlar, FGF-2 ve CNP-3'ün, CAM gelişimi ve ileri vasküler organizasyon sürecinde anjiyogenezin ileri ve geç aşamalarında rol oynayabileceğini düşündürmüştür. Ayrıca, E16'da embriyonun artan büyüklüğüne paralel olarak artan oksijenizasyon ihtiyacının da CNP-3 ve FGF-2 ifadesini uyarmış olabileceği yorumlanmıştır.

Sonuç olarak bu çalışma, VEGF-A ve FGF-2 tarafindan düzenlenen anjiyogenik sinyal yolaklarına paralel olarak, CAM yapısında görülen anjiyogenez sürecinde CNP-3/NPR-B sinyal yolağının da etki mekanizmasını araştırabilecek gelecekteki çalışmaların temelini oluşturmaktadır. CAM vasküler gelişimi sırasında CNP3/NPR-B sinyal yolağının anjiyogenezdeki etki mekanizmasını açıklayabilmek için daha fazla fonksiyonel çalışmaya ihtiyaç vardır.

Etik Kurul Onay Bilgisi:

Onaylayan Kurul: Başkent Üniversitesi Tıp ve Sağlık Araştırma

Kurulu

Onay Tarihi: 14.10 .2020

Karar No: 12/10/2020 tarih ve 20/14 sayıli karar

\section{Araştırmacı Katkı Beyanı:}

Fikir ve tasarım: A.Ç.T., E.E.; Veri toplama ve işleme: A.Ç.T., E.E., F.F.K.; Analiz ve verilerin yorumlanması: A.Ç.T., E.E., A.D.; Makalenin önemli bölümlerinin yazılması: A.Ç.T., E.E., A.D., F.F.K.

\section{Destek ve Teșekkür Beyanı:}

Bu makalede yer alan çalışmalar DA20/14 nolu proje kapsamında Başkent Üniversitesi tarafindan desteklenmiştir.

Başkent Üniversitesi Tip Fakültesi Histoloji ve Embriyoloji Anabilim Dalından Uzman Biyolog Ece Lakşe Coşar'a elektron mikroskop numunelerinin hazırlanmasında verdiği destekten dolayı teşekkür ederiz.

\section{Çıkar Çatışması Beyanı:}

Makale yazarlarının çıkar çatışması beyanı yoktur.

\section{Kaynaklar}

1. Noden DM. Embryonic origins and assembly of blood vessels. Am Rev Respir Dis 1989; 140: 1097-1103.

2. Poole TJ, Coffin JD. Vasculogenesis and angiogenesis: two distinct morphogenetic mechanisms establish embryonic vascular pattern. J Exp Zool 1989; 251: 224-231.

3. Risau, W. Vasculogenesis, angiogenesis and endothelial cell differentiation during embryonic development; in Feinberger, R.N., G.K. Sherer, R. Auerbach (eds): The Development of the Vascular System. Issues in Biomedicine. Basel Karger 1991; 14: 58-68.

4. Edward MC, De'sire' C, Peter C. Molecular mechanisms of blood vessel growth. Cardiovascular Research 2001; 49: 507521.

5. Naito H, Iba T, Takakura N. Mechanisms of new blood-vessel formation and proliferative heterogeneity of endothelial cells. Int Immunol 2020; 32: 295-305.

6. Giles JJ, Bannigan JG. The effects of lithium on vascular development in the chick area vasculosa. J Anat 1999; 194: 197-205.

7. Patan S. Vasculogenesis and angiogenesis as mechanisms of vascular network formation, growth and remodeling. J Neurooncol 2000; 50: 1-15.

8. Tufan A.C., Satıroglu-Tufan N.L. The effect of ethanol exposure on extraembryonic vascular development in the chick area vasculosa. Cells Tissues Organs 2003; 175:85-97

9. Risau W. Mechanism of angiogenesis. Nature 1997; 386: 671-4.

10. Carmeliet P. Mechanisms of angiogenesis and arteriogenesis. Nat Med 2000; 6(4): 389-95.

11. Kachooei SA, Rahmani R, Zareh N, et al. Down-regulation of TGF- $\beta$, VEGF, and bFGF in vascular endothelial cells of chicken induced by a brittle star (Ophiocoma erinaceus) extract. Heliyon 2020; 6: e03199.

12. Cébe-Suarez S, Zehnder-Fjällman A, Ballmer-Hofer K. The role of VEGF receptors in angiogenesis; complex partnerships. Cell Mol Life Sci 2006; 63(5): 601-615.

13. Cao R, Eriksson A, Kubo H, et al. Comparative Evaluation of FGF-2-, VEGF-A-, and VEGF-C induced angiogenesis, lymphangiogenesis, vascular fenestrations, and permeability. Circulation Research 2004; 94:664-670.

14. Yancopoulos GD, Davis S, Gale NW, et al. Vascular-specific growth factors and blood vessel formation. Nature 2000; 14;407(6801):242-8.

15. Leconte I, Fox JC, Baldwin HS, et al. Adenoviral-mediated expression of antisense RNA to fibroblast growth factors disrupts murine vascular development. Dev Dyn. 1998; 213: 42130.

16. Lee SH, Schloss DJ, Swain JL. Maintenance of vacsular integrity in the embryo requires signaling through the fibroblast growth factor receptor. J Biol Chem 2000; 275: 33679-87.

17. Javerzat S, Auguste P, Bikfalvi A. The role of fibroblast growth factors in vascular development. Trends Mol Med. 2002; 8: 483-9.

18. Bikfalvi A, Klein S, Pintucci G, et al. Biological roles of fibroblast growth factor-2. Endocr Rev 1997; 18: 26-45.

19. Bahramsoltani M, Spiegelaere WD, Janczyk P, et al. Quantitation of angiogenesis in vitro induced by VEGF-A and FGF-2 in two different human endothelial cultures - an all-in-one assay. Clin Hemorheol and Microcirc 2010; 46:189-202.

20. Joseph-Silverstein J, Rifkin DB. Endothelial cell growth factors and the vessel wall. Semin Thromb Hemost 1987; 13: 504-13.

21. Klagsbrun M, D'Amore PA. Regulators of angiogenesis. Annu Rev Physiol 1991; 53: 217-39. 


\section{Anjiyogenez Sürecinde CNP-3 ve NPR-B Ekspresyonu}

22. Olney RC, Bukulmez H, Bartels CF, et al. Heterozygous mutations in natriuretic peptide receptor- B (NPR2) are associated with short stature. J Clin Endocrinol Metab 2006; 91: 12291232.

23. Alan T, Tufan AC. C-Type Natriuretic Peptide Regulation of Limb Mesenchymal Chondrogenesis is Accompanied by Altered N-Cadherin and Collagen Type X-Related Functions. J. Cell Biochem 2008; 105: 227-235.

24. Stingo AJ, Clavell AL, Heublein DM, et al. Presence of C-type natriuretic peptide in cultured human endothelial cells and plasma. Am J Physiol 1992; 263: H1318-21.

25. Špiranec K, Chen W, Werner F, et al. Endothelial c-type natriuretic peptide acts on pericytes to regulate microcirculatory flow and blood pressure. Circulation 2018; 138: 494-508.

26. Potter LR, Abbey-Hosch S, Dickey DM. Natriuretic peptides, their receptors, and cyclic guanosine monophosphate-dependent signaling functions. Endocr Rev. 2006; 27: 47-72.

27. 27. Rose RA, Giles WR. Natriuretic peptide c receptor signaling in the heart and vasculature. J Physiol 2008; 586: 353-366.

28. Suga S, Nakao K, Itoh $\mathrm{H}$, et al. Endothelial production of ctype natriuretic peptide and its marked augmentation by transforming growth factor-beta. Possible existence of "vascular natriuretic peptide system". J Clin Invest. 1992; 90: 1145-9.

29. Moyes AJ, Hobbs AJ. C-type natriuretic peptide: a multifaceted paracrine regulator in the heart and vasculature. Int J Mol Sci. 2019; 20: 2281.

30. Lumsden NG, Khambata RS, Hobbs AJ. c-type natriuretic peptide (CNP): cardiovascular roles and potential as a therapeutic target. Curr Pharm Des. 2010; 16: 4080-8.

31. Bubb KJ, Aubdool AA, Moyes AJ, et al. Endothelial c-type natriuretic peptide is a critical regulator of angiogenesis and vascular remodeling. Circulation. 2019; 139: 1612-1628.

32. Umaru B, Pyriochou A, Kotsikoris V, et al. ATP-sensitive potassium channel activation induces angiogenesis in vitro and in vivo. J Pharmacol Exp Ther 2015; 354: 79-87.

33. Woodard GE, Rosado JA, Brown J. Expression and control of c-type natriuretic peptide in rat vascular smooth muscle cells. Am J Physiol Regul Integr Comp Physiol. 2002; 282: R156-65.

34. Houweling AC, Somi S, Massink MP, et al. Comparative analysis of the natriuretic peptide precursor gene cluster in vertebrates reveals loss of ANF and retention of cnp-3 in chicken. Dev Dyn 2005; 233: 1076-1082.

35. Kocamaz E, Gok D, Cetinkaya A, et al. Implication of c-type natriuretic peptide-3 signaling in glycosaminoglycan synthesis and chondrocyte hypertrophy during TGF- $\beta 1$ induced chondrogenic differentiation of chicken bone marrow-derived mesenchymal stem cells. J Mol Histol 2012; 43: 497-508.

36. Merckx G, Tay H, Lo Monaco M, et al. Chorioallantoic membrane assay as model for angiogenesis in tissue engineering: focus on stem cells. Tissue Eng Part B Rev 2020; doi: 10.1089/ten.TEB.2020.0048.

37. Ribatti D. The chick embryo chorioallantoic membrane (CAM) A multifaceted experimental model. Mech Dev 2016; 141: 7077.

38. Patrycja NS, Tatiana S, M. Luisa IA. The chicken chorioallantoic membrane model in biology, medicine and bioengineering, Angiogenesis 2014; 17: 779-804.

39. Ergin C, Tufan AC, Yılmaz C. Bartonella Henselae tarafindan uyarılan anjiogenezin, in vivo model olarak yumurta açı̆̆ında, kabuksuz tavuk embriyosu kültürü üzerinde, koryoallantoik membranda gösterilmesi. Nobel Med 2012: 8: 108-112.

40. Tufan AC, Satiroglu-Tufan NL. The chick embryo chorioallantoic membrane as a model system for the study of tumor angiogenesis, invasion and development of anti-angiogenic agents. Curr Cancer Drug Targets 2005; 5: 249-66.

41. Baum O, Suter F, Gerber B, et al. VEGF-A promotes intussusceptive angiogenesis in the developing chicken chorioallantoic membrane. Microcirculation 2010; 17: 447-457.

42. Richardson, M.; Singh, G. Observations on the use of the avian chorioallantoic membrane (CAM) model in investigations into angiogenesis. Curr. Drug Targets-Cardiovasc. Haematol. Disord 2003; 3:155-185.

43. Ribatti D, Nico B, Vacca A, et al. Chorioallantoic membrane capillary bed: a useful target for studying angiogenesis and anti-angiogenesis in vivo. Anat. Rec 2001; 264:317-324.

44. Ribatti D, Presta M. The role of fibroblast growth factor-2 in the vascularization of the chick embryo chorioallantoic membrane. J. Cell Mol. Med. 2002; 6: 439-446.

45. Schlatter P, Konig MF, Karlsson LM, et al. Quantitative study of intussusceptive capillary growth in the chorioallantoic membrane (CAM) of the chicken embryo. Microvasc. Res. 1997; 54: 65-73.

46. Miller SA, Bresee KL, Michaelson CL, et al. Domains of differential cell proliferation and formation of amnion folds in chick embryo ectoderm. Anat. Rec 1994; 238: 225-236.

47. DeFouw DO, RizzoVJ, Steinfeld R, et al. Mapping of the microcirculation in the chick chorioallantoic membrane during normal angiogenesis. Microvasc. Res 1989; 38: 136-147.

48. Wangenstein D, Weibel ER. Morphometric evaluation of chorioallantoic oxygen transport in the chick embryo. Respir. Physiol. 1982; 47: 1-20.

49. Ausprunk DH, Knighton DR, Folkman J. Differentiation of vascular endothelium in the chick chorioallantois: a structural and autoradiographic study. Dev. Biol 1974; 38: 237-248.

50. Makanya AN, Dimova I, Koller T, et al. Dynamics of the developing chick chorioallantoic membrane assessed by stereology, allometry, immunohistochemistry and molecular analysis. PLoS One. 2016; 5: e0152821.

51. Marinaccio C, Nico B, Ribatti D. Differential expression of angiogenic and anti-angiogenic molecules in the chick embryo chorioallantoic membrane and selected organs during embryonic development. Int J Dev Biol 2013; 57: 907-16.

52. Presta M, Dell'Era P, Mitola S, et al. Fibroblast growth factor/fibroblast growth factor receptor system in angiogenesis. Cytokine Growth Factor Rev 2005;16: 159-78.

53. Kano MR, Morishita Y, Iwata C, et al. VEGF-A and FGF-2 synergistically promote neoangiogenesis through enhancement of endogenous PDGF-B-PDGFR-beta signaling. J Cell Sci 2005; 118: 3759-68.

54. Ribatti D, Urbinati C, Nico B, et al. Endogenous basic fibroblast growth factor is implicated in the vascularization of the chick embryo chorioallantoic membrane. Dev Biol. 1995; 170: 39-49.

55. Yang X, Liaw L, Prudovsky I, et al. Fibroblast growth factor signaling in the vasculature. Curr Atheroscler Rep 2015; 17: 509.

56. Pedram A, Razandi M, Levin ER. Natriuretic peptides suppress vascular endothelial cell growth factor signaling to angiogenesis. Endocrinology. 2001; 142: 1578-86. 
